\title{
First records of the sponge crab Dromia personata (Brachyura) in the Netherlands and its historical findings in the North Sea
}

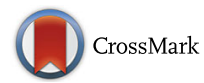

\author{
Godfried W. N. M. van Moorsel ${ }^{1 *}$, Floris P. Bennema² and Reindert Nijland ${ }^{3} \mathbb{C}$
}

\begin{abstract}
Only a few records exist of the sponge crab Dromia personata in the North Sea. Most records are in local languages, and have limited availability. On 11 August 2016, D. personata was found by divers in the Eastern Scheldt, a former estuary in the south-western part of the Netherlands. In the months to follow, at least four other individuals were observed by divers at the same and nearby locations. This paper lists these and former records in the North Sea. The distribution pattern, and the possible migration of the sponge crab in relation to environmental conditions such as seawater temperature are discussed, as well as the crab's use of the non-native sponge Celtodoryx ciocalyptoides.
\end{abstract}

Keywords: Sponge crab, Dromia personata, North Sea, Southern species, Distribution expansion

\section{Background}

Geographic distribution: Dromia personata (Linnaeus, 1758) is known from the Mediterranean Sea, and in the East Atlantic Ocean from Western Sahara, Ascension, Azores and Canary Islands, north to Anglesey (Wales), the Clyde Sea (Scotland) and the English Channel. North Sea records are rare (see below and Fig. 1). Records from São Tomé, Senegal, Cabo Verde and Madeira and possibly also St. Helena refer to Dromia marmorea Forrest, 1974 (Christiansen 1969; Manning and Holthuis 1981; Wolff 2002; Ashton et al. 2017; Allen 1967; González 2016; González et al. 2017; Araújo and Wirtz 2015; De Grave et al. 2017). Morphological differences between $D$. personata and D. marmorea are discussed in Manning \& Holthuis (1981). In British waters, the sponge crab has been recorded infrequently. In Ireland, the first specimens of $D$. personata were caught only recently, in 2010 and 2011 (Quigley and O'Donovan 2013).

Only a few records of sponge crabs from the North Sea exist (Fig. 1). In 1824, two specimens were found at Billingsgate Market (London) among oysters from Whitstable Bay (Anonymous 1824); this was the first record from the United Kingdom (Bell 1853). Another specimen was caught in 1880 'in deep water of the open sea'

\footnotetext{
* Correspondence: vanmoorsel@ecosub.nl

'ecosub, P.O. Box 126, 3940 AC Doorn, The Netherlands

Full list of author information is available at the end of the article
}

off the Belgian coast (Pelseneer 1881). In 1912, D. personata was caught in the vicinity of the 'Galloper' light vessel off the Essex coast (Patterson 1913). Leloup (1941) lists a record from 1937 near the Sandettie Bank at $19-20$ fathoms $(35-37 \mathrm{~m})$. This bank lies north of Calais, in what is now the French part of the North Sea. A footnote in Leloup (1941) mentions two more specimens, also from 1937, caught at the White Bank, the now submerged west bank of the Elbe glacial valley. Although this area is $170 \mathrm{~km}$ west of Denmark, it lies just east of $6^{\circ}$ latitude, and was therefore considered to belong to the Danish fauna (Wolff 2002). The rectangular area specified in Leloup (1941) presently lies in the German part of the North Sea (Fig. 1) and is roughly equidistant from the Dutch, German and Danish coast. The designation of the latitude in the footnote in Leloup (1941) in multiples of $15^{\prime}$ suggests a possible error in the eastern longitude: it is probably not $\mathrm{E} 6^{\circ} 3^{\prime}$ but $\mathrm{E} 6^{\circ}$ $30^{\prime}$. This also better fits the location of the White Bank, at approximately $\mathrm{N} 55^{\circ} 10^{\prime}$ and $\mathrm{E} 6^{\circ} 10^{\prime}$. The last specified site in the North Sea, in 1953, is the Fairy Bank (Adema 1981) in the French part of the North Sea. In addition, Ingle (1983) mentions the Wash and Thames as North Sea locations. The latter record is possibly also included in Adema (1991), which shows three locations at the English North Sea coast, off Kent and Norfolk. Leloup \& Gills (1965) report D. personata from shrimp 


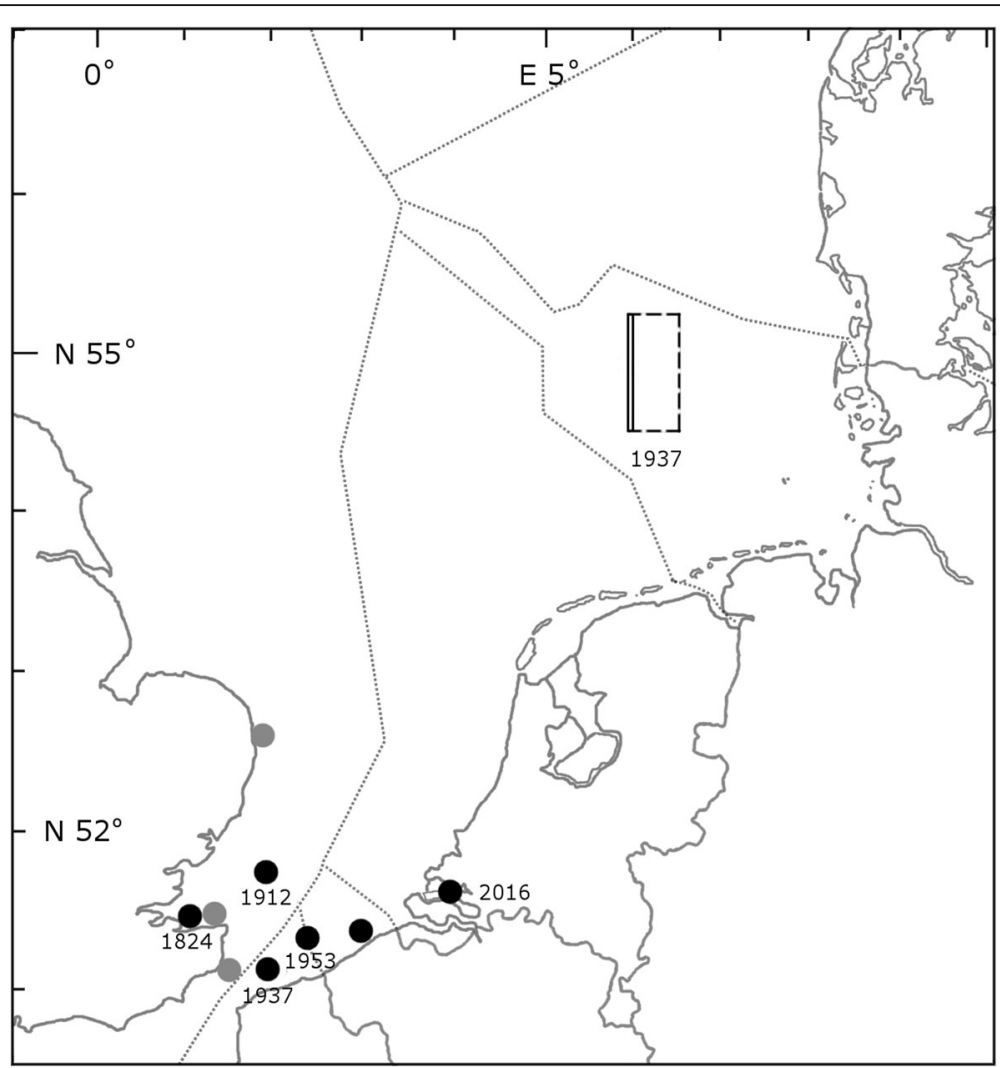

Fig. 1 Records of Dromia personata in the southern North Sea. Locations of records in the southern North Sea with boundaries of national continental flats and year of catch or observation where available. Grey symbols from Adema (1991). Left part of rectangle in the German part of the North Sea is the area of two catches in 1937 as mentioned in Leloup (1941); whole rectangle (including interrupted line) is probable area of occurrence (see text)

catches during 1949-1964, in a $25 \mathrm{~km}$ long strip inside the 5 -mile $(9 \mathrm{~km})$ zone from the Belgian coast between Middelkerke and Wenduine. They call the crab as being 'assez rare', the one but lowest of their four abundance categories, which suggests the catch of at least several specimens. Coordinates of the above-mentioned historic North Sea records are listed in Table 1.

\section{Methods}

New records in the Netherlands emerged by observations made via SCUBA diving. The first Dutch record of Dromia personata was posted on 16 August 2016 on the internet (NatureToday.com) and prompted other biologists and diving naturalists to search for the species. This resulted in findings that were sometimes accompanied by underwater photos (Fig. 2) or video. As such, this paper shows the valuable contribution of citizen science (Thiel et al. 2014). Due to its sponge cover $D$. personata is well camouflaged, but once found it was easily recognized and could not be confused with other brachyurans.

\section{Results}

In 2016, several individuals of Dromia personata were found in the Eastern Scheldt, and these constituted the first records in the Netherlands. One was found on 11 August 2016, and was taken from its location (Zeelandbrug: $51^{\circ} 37^{\prime} 44^{\prime \prime} \mathrm{N}, 3^{\circ} 54^{\prime} 49^{\prime \prime}$ E). Subsequently, at least 12 times between 14 August and 30 October 2016, D. personata was recorded (but not collected) again at the same location. The maximum number of sponge crabs observed per dive was two. Consequently, a minimum number of three individuals must have been present at the Zeelandbrug. The relatively high number of records at this location may reflect the popularity of this dive site. In addition, two more sponge crabs were found in the Eastern Scheldt, at Strijenham $\left(51^{\circ} 31^{\prime} 17^{\prime \prime} \mathrm{N}, 4^{\circ} 08^{\prime} 28^{\prime \prime} \mathrm{E}\right)$ and Goesse Sas $\left(51^{\circ} 32^{\prime} 32^{\prime \prime} \mathrm{N}, 3^{\circ} 55^{\prime} 52^{\prime \prime}\right.$ E). Considering the distance between these locations and the timing it is highly unlikely that these records represented the same individuals. Therefore, a total of at least five sponge crabs must have been present in the Eastern Scheldt in 2016. 


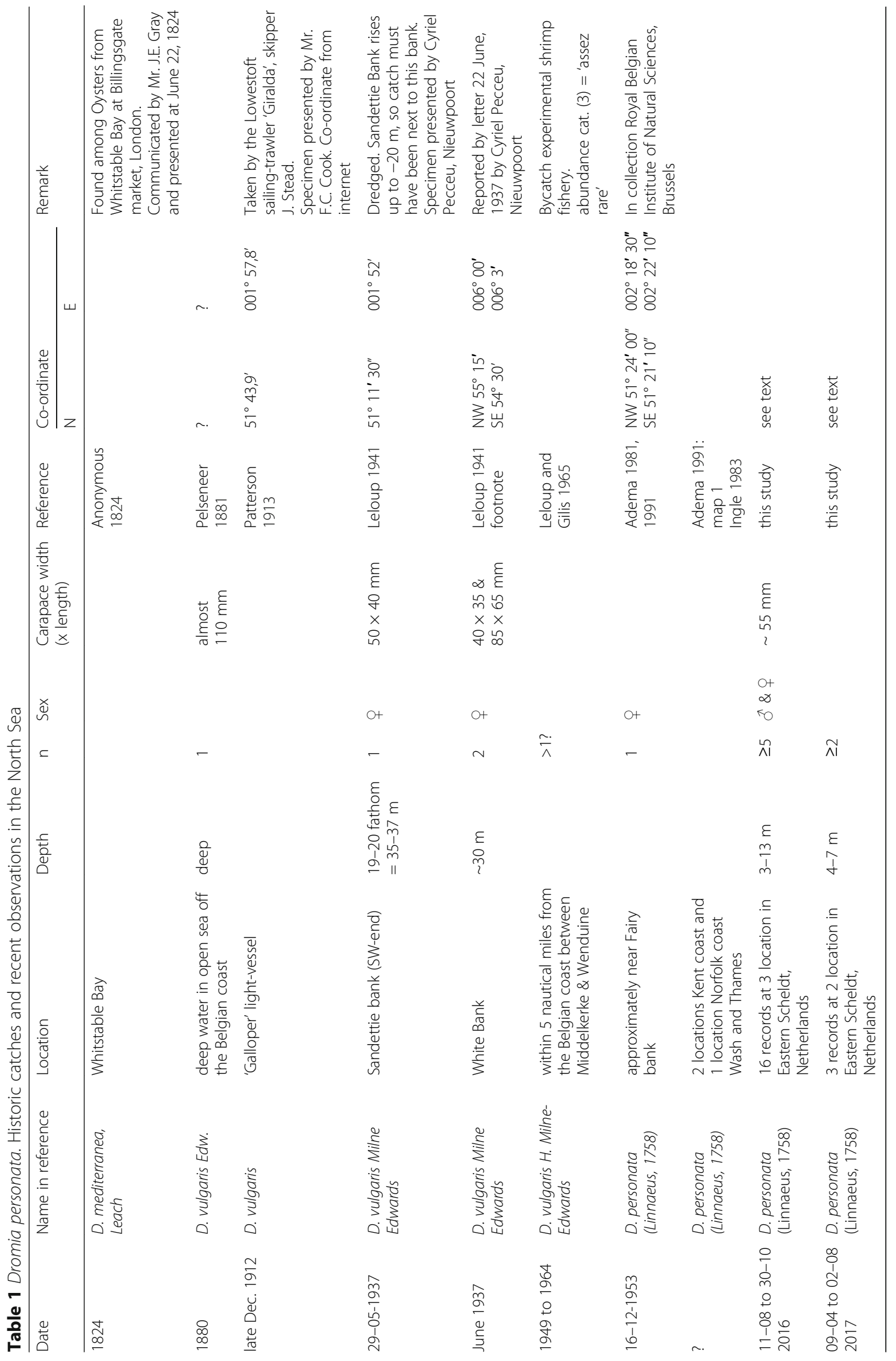




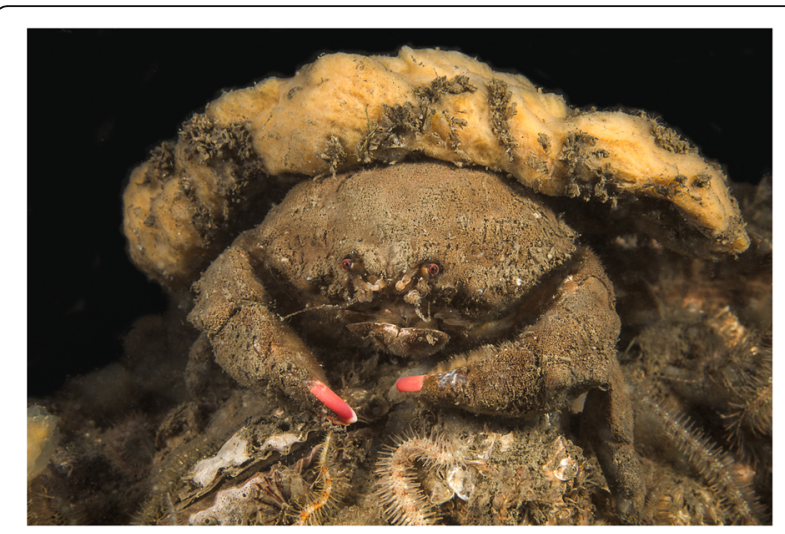

Fig. 2 Dromia personata in situ, 6 October 2016, Zeelandbrug, Eastern Scheldt. Underwater photo by Mick Otten

In 2017, at least two individuals of Dromia personata were sighted in the Eastern Scheldt. On 9 April, a moribund sponge crab without cover was found at the Zeelandbrug and on 27 July and 2 August, a sponge crab was seen at Schelphoek (51 41' 02" N, 003 49 $07^{\circ}$ " E). This indicates that the local occurrence is not limited to a single-season event.

The carapace width of the first crab found was $55 \mathrm{~mm}$, and the other crabs were of similar size. Both sexes were encountered; the females were nonovigerous. In 2016, all sponge crabs were found with a cover of either the native sponge Halichondria panicea, or the non-indigenous sponge Celtodoryx ciocalyptoides. The crab of 27 July 2017 carried the soft coral Alcyonium digitatum on its back. As far as we know, only sponges and tunicates have been recorded as natural cover material. Therefore, this is the first case of a sponge crab with an alcyonacean cover. During the 2016 recording period, seawater temperature was $20{ }^{\circ} \mathrm{C}$ in August, dropping to $13{ }^{\circ} \mathrm{C}$ at the end of October.

The 2016 and 2017 Dutch records are summarized in Table 1. Detailed information is provided in Additional file 1.

\section{Discussion}

Almost 200 years after the first record of Dromia personata in the North Sea, about 10 records are known from this continental sea. Approximate coordinates of catch locations could be deduced from the literature for only 4 specimens, the last one from 1953, which is 63 years before the present records. The discovery of at least 5 individuals, both males and females, at three locations in the Eastern Scheldt in 2016 constitutes a relatively large addition to both the number of records and the total number of individuals.

Considering the rarity of this species in the North Sea, finding at least 5 sponge crabs in such a short time frame is remarkable. On the other hand, finding several individuals within 1 year has happened before: in 1824 two specimens were found, and in 19373 specimens were reported. In Ireland, the first two specimens were found only 8 months apart in 2010 and 2011 (Quigley and O'Donovan 2013). Possibly, this species shows rapid expansions in certain years only.

Because Dromia personata is a Lusitanian species that reaches the limit of its northern distribution in the southern North Sea, its presence may be expected in years with high water temperatures. In recent decades, seawater temperatures have increased in the area and several species have demonstrated a northward shift in distribution (van der Kooij et al. 2016; Franke and Gutow 2004; Hiscock et al. 2004). Therefore, the chance of encountering the sponge crab in the Netherlands may also be increasing. This possibility is supported by other northern records of $D$. personata in the last decade: the first two Irish records (Quigley and O'Donovan 2013), and an increased occurrence in the Bristol Channel (Ashton et al. 2017).

Moreover, environmental conditions in the Eastern Scheldt may increasingly favour the presence of this species. In 1986, the Eastern Scheldt barrier was completed. This still allows a tidal regime, but tidal currents are diminished and light attenuation is decreased. The hardsubstratum ecosystem has changed dramatically, notably due to the alien Japanese oyster Magallana gigas. Also, sponges and tunicates, used as camouflage by the sponge crab, are now omnipresent. Sponge crabs were observed not only bearing the native breadcrumb sponge Halichondria panicea but also the non-native sponge Celtodoryx ciocalyptoides. In recent years, thick layers of $C$. ciocalyptoides have developed into one of the most abundant sponges in the Eastern Scheldt (pers. obs.). Therefore, this sponge offers a favourable resource for crabs in search of cover material.

The distribution of Dromia personata suggests migration into the North Sea from the English Channel, either as larvae or as adults. As the last two pairs of the crab's pereiopods are used for sponge-attachment, only two pairs of legs are used for locomotion. Although $D$. personata is able to walk at considerable speed over short distances if necessary (pers. obs.), its capacity to walk over long distances, for example from the English Channel to the Eastern Scheldt, is probably limited. The importance of larval transport should therefore not be underestimated. In recent years, several wind farms have been built in the Belgian part of the North Sea. The seabed around the wind turbines has been covered with stones. Perhaps these areas are used for settlement of sponge-crab larvae. As such, they may function as stepping stones between the English Channel and the Eastern Scheldt. However, underwater observations and catches, preferably of juveniles, have not yet been made to confirm this. 
Finally, the appearance of the sponge crab may also be related to accidental introduction via mariculture, but this scenario is considered unlikely, due to absence or rarity in donor areas, and probably low survival during transport.

\section{Conclusions}

At least five individuals of Dromia personata were found in the Eastern Scheldt in the Netherlands in 2016 and 2017. These findings extend the known distribution range of this crab species and suggest a sudden increase in abundance.

\section{Additional file}

Additional file 1: Sponge crab (Dromia personata): Observations in the Eastern Scheldt, Netherlands, in 2016 and 2017. (XLSX 22 kb)

\section{Acknowledgements \\ We would like to thank Glen Biscop, Marianne Ligthart, Marco Vinke, Carl Verlinde, Martin Gruson, Stefan Verheyen, René van Zweden, Lilian Schoonderwoerd, Paul \& Maria Engels, Kris'na Wouters, Mick Otten, Hans Vulink, Maurits van Kosteren and Astrid Vis for providing data and agreeing to its use in this manuscript. Furthermore, we thank Danny Eibye-Jacobsen, who kindly provided a pdf of Wolff 2002. We gratefully acknowledge the help of Susan Hewitt in checking writing style, spelling and grammar.}

\section{Funding}

This study was self-funded.

\section{Availability of data and materials}

All data generated or analysed during this study are included in this published article and its supplementary information files.

\section{Authors' contributions}

FB and GVM made the initial observation leading to this report. GVM, FB and RN collected further observations, analysed the data and wrote the manuscript. All authors read and approved the final manuscript.

\section{Authors' information}

GvM is an independent marine ecologist and consultant. FB is a biologist focussing on marine ecology and research of historic data to reconstruct the composition of marine communities before intensive fisheries took their toll. RN is a molecular microbiologist at the Marine Animal Ecology group at Wageningen UR, with a strong interest in Dutch crustaceans. All three authors are avid scuba-divers and have logged hundreds of hours underwater in Dutch coastal waters

\section{Ethics approval and consent to participate}

Not applicable

\section{Consent for publication}

All persons contributing to this manuscript have consented that their data and personal details will be published.

\section{Competing interests}

The authors declare that they have no competing interests.

\section{Publisher's Note}

Springer Nature remains neutral with regard to jurisdictional claims in published maps and institutional affiliations.

\section{Author details}

'ecosub, P.O. Box 126, 3940 AC Doorn, The Netherlands. ${ }^{2}$ Vincent van Goghstraat 88, 8932 LK Leeuwarden, The Netherlands. ${ }^{3}$ Marine Animal Ecology Group, Wageningen University, P.O. Box 338, 6700 AH Wageningen, The Netherlands.
Received: 4 August 2017 Accepted: 30 October 2017

Published online: 10 November 2017

\section{References}

Adema JPHM. Een bijzondere krab in de Vlaamse wateren. De Strandvlo. 1981;1: 29-31.

Adema JPHM. De krabben van Nederland en België (Crustacea, Decapoda, Brachyura). Leiden: Nationaal Natuurhistorisch Museum; 1991.

Allen JA. The fauna of the Clyde sea area: Crustacea: Euphausiacea and Decapoda with an illustrated key to the British species. Millport: Scottish Marine Biological Association; 1967.

Anonymous. Proceedings of the zoological club of the Linnean Society. Zool J. $1824 ; 1: 418-21$.

Araújo R, Wirtz P. The decapod crustaceans of Madeira Island - an annotated checklist (Crustacea, Decapoda). Spixiana. 2015:38:205-18.

Ashton GV, Brandt A, Isaac MJ, Makings P, Moyse J, Naylor E, Smaldon G, Spicer J. Crustaceans. In: Hayward PJ, Ryland JS, editors. Handbook of the marine fauna of North-West Europe. 2nd ed. Oxford: Oxford University press; 2017. p. 283-440.

Bell T. A history of the British stalk-eyed crustacea / by Thomas Bell. London: Van Voorst; 1853.

Christiansen ME. Crustacea Decapoda Brachyura. Oslo: Norvegian University Press; 1969.

De Grave S, Anker A, Dworschak PC, Clark PF, Wirtz P. An updated checklist of the marine Decapoda of Ascension Island, central Atlantic Ocean. J Mar Biol Assoc U K. 2017:97:759-70.

Franke H-D, Gutow L. Long-term changes in the macrozoobenthos around the rocky island of Helgoland (German Bight, North Sea). Helgol Mar Res. 2004; 58:303-10.

González JA. Brachyuran crabs (Crustacea: Decapoda) from the Canary Islands (eastern Atlantic): checklist, zoogeographic considerations and conservation. Sci Mar. 2016;80:14.

González JA, Triay-Portella R, Martins A, Lopes E. Checklist of brachyuran crabs (Crustacea: Decapoda) from the Cape Verde Islands, with a biogeographic comparison with the Canary Islands (Eastern Atlantic). Cah Biol Mar. 2017;58: $137-51$.

Hiscock K, Southward A, Tittley I, Hawkins S. Effects of changing temperature on benthic marine life in Britain and Ireland. Aquat Conserv Mar Freshwat Ecosyst. 2004;14:333-62.

Ingle RW. Shallow-water crabs. Cambridge: Cambridge University Press; 1983.

Leloup E. Contributions à l'étude de la faune belge: XI. Les Crustacés Décapodes Brachyoures de la côte belge. Bulletin du Musée royal d'Histoire naturelle de Belgique. 1941;XVII (11):1-19.

Leloup E, Gilis C. Zeedieren waargenomen in de experimentele garnalenvangsten (1949-1964). Studies van het Zeewetenschappelijk Instituut Oostende. 1965;2: $1-26$.

Manning RB, Holthuis LB. West African brachyuran crabs (Crustacea, Decapoda). Smithson Contr Zool. 1981:306:1-379.

Patterson AH. Dromia vulgaris off the Essex coast. The Zoologist. 1913;4:38.

Pelseneer P. Etudes sur la faune littorale de la Belgique (vers chétopodes et Crustacés). Annales de la Société Royale Malacologique de Belgique. 1881;16: 88-98.

Quigley DTG, O'Donovan BC. First records of the sponge crab Dromia personata (L.) (Crustacea: Decapoda: Brachyura) from Irish waters. Irish Nat J. 2013;33: 64-5.

Thiel M, Penna-Díaz M, Luna-Jorquera G, Salas S, Sellanes J, Stotz W. Citizen scientists and marine research: volunteer participants, their contributions, and projection for the future. In: Oceanography and marine biology. Boca Raton: CRC Press; 2014;52:257-314. - An Annual Review].

van der Kooij J, Engelhard GH, Righton DA. Climate change and squid range expansion in the North Sea. J Biogeogr. 2016;43:2285-98.

Wolff T. To krabber, Dromia personata og Paramola cuvieri, nye for Danmark, en krabbe under mulig udbredelse mod Danmark samt om mudderkrebsen Axius nodulosus. Flora og fauna. 2002;108:87-94. 